\title{
Efforts to Revitalize Student Learning Motivation After the COVID-19 Pandemic
}

\author{
Dedi Riyan Rizaldi \\ Madrasah Aliya Plus Nurul Islam Sekarbela Mataram, Indonesia \\ Email:dedio313@gmail.com
}

\section{Muhamad Zaenudin}

Madrasah Aliya Plus Nurul Islam Sekarbela Mataram, Indonesia

Email:dedio313@gmail.com

\section{Ziadatul Fatimah}

Senior High School NW Mataram, Indonesia

Email:dedio313@gmail.com

\section{Asep L Hamdun Ahmad}

Radix Indonesia Emas Foundation Mataram, Indonesia

Email:dedio313@gmail.com

\section{Heru Setiawan}

Radix Indonesia Emas Foundation Mataram, Indonesia

Email:dedio313@gmail.com

Aris Doyan

University of Mataram, Mataram, Indonesia

Email:dedio313@gmail.com

\section{Muh. Makhrus}

University of Mataram, Mataram, Indonesia

Email:dedio313@gmail.com

DOI: https://doi.org/10.21154/sajiem.v3i1.87 


\begin{abstract}
This study aims to regenerate and increase students' learning motivation after experiencing a long learning process from home due to the impact of the COVID-19 pandemic through Training for Leaders and Herbalists (TRALIS). This study uses a qualitative approach, namely the type of field research (Field Research) by focusing on the observation method. The object of this research is all students of class XII in the Department of Religion at Madrasah Aliyah Plus Nurul Islam Sekarbela with a total of 31 students. Based on the activities that have been carried out, Training for Leaders and Herbalists (TRALIS) is one form of positive activity that is very important given to students to revive enthusiasm for participating in teaching and learning activities in madrasas. This activity provides many new changes for students during the learning process including students having a strong sense of desire to participate in every activity carried out, increasing self-confidence which is seen through the attitude of students who are not afraid to appear in front of the class and express opinions during the class discussion process.
\end{abstract}

Keywords: Post COVID-19 Pandemic, Learning motivation, Training for Leaders and Herbalists (TRALIS)

\title{
Introduction
}

Educational conditions that currently tend to be dynamic or change over time will always bring changes in all aspects or components of a learning system. ${ }^{1}$ If we refer to the madrasa environment or we can call it the environment between teachers and students, we often encounter problems that can affect the learning process so that it will have an impact on predetermined goals ${ }^{2}$. One of the problems found due to the current prolonged COVID-19 pandemic is the decline in student learning motivation ${ }^{3}$. Of course, if this condition is not immediately followed up by the teacher, it

${ }^{1}$ Rizaldi, Dedi Riyan, Aris Doyan, Muh Makhrus, Ziadatul Fatimah, and Eris Nurhayati. "Adaptation to new normal conditions: Students physics learning outcomes using the blended learning model." International Journal of Asian Education 2, no. 3 (2021):369-376

${ }^{2}$ Cahyani, Adhetya, Iin Diah Listiana, and Sari Puteri Deta Larasati. "Motivasi Belajar Siswa SMA pada Pembelajaran Daring di Masa Pandemi Covid-19." IQ (Ilmu Al-qur'an): Jurnal Pendidikan Islam 3, no. o1 (2020): 123-140.

${ }^{3}$ Cahyono, Hadi. "Faktor-Faktor Kesulitan Belajar Siswa Min Janti." JDPP Jurnal Dimensi Pendidikan dan Pembelajaran 7, no. 1 (2019): 1-4. 
can disrupt the teaching and learning process and will have a direct impact on student learning outcomes. Therefore we need an encouragement that can grow and increase the enthusiasm or motivation of students in learning.

Increasing student motivation in learning is very important for teachers or parents. This is because motivation has a very important function and role in an activity, which will affect the strength of the activity itself ${ }^{4}$. In addition, this condition will provide students with a re-view of the various hidden potentials within the students themselves. The tendency is basically in students to actually have various skills that just can't appear because of a lack of self-confidence.

When viewed from the facts that occur in the field, it looks contrary to the teacher's desire so that students can be more motivated in terms of participating in the learning process activities. Lack of self-motivation to learn in students turns out to be a confusing problem for teachers ${ }^{6}$, for example, many students fall asleep during the learning process, ignore the teacher's explanation and there are many other problems. Some of these examples are very serious problems experienced by most teachers today, especially at Madrasah Aliyah Plus Nurul Islam due to the COVID-19 pandemic which tends to make students prioritize the time they have to do activities outside of learning activities. So, with these problems, a treatment was carried out through the application of Training for Leaders and Herbalists (TRALIS) activities to all class XII students of the Department of Religion at Madrasah Aliyah Plus Nurul Islam Sekarbela.

\section{Research Methods}

This study uses a qualitative approach, namely the type of field research (Field Research) by focusing on the observation method. This study focuses on the delivery of motivation to students of Class XII Department of Religion in the Madrasah Aliyah Plus Nurul Islam Sekarbela. This method focuses on studying and describing Training for Leaders and Herbalists (TRALIS) activities in increasing students' learning motivation under the affiliation of the Radix Indonesia Emas Foundation in the Madrasah Aliyah Plus Nurul Islam Sekarbela Even Semester Academic Year 2021/2022.

${ }^{4}$ Setiawan, Farid, Dias Syahrul Riyadi, Shinta Ledia, and Yayan Bagus Duandanto. "Peran Pendidik dalam Meningkatkan Manajemen Sekolah pada Masa Pandemi." MASALIQ 1, no. 3 (2021): 33-49.

${ }^{5}$ Harisuddin, Muhammad Iqbal. Secuil Esensi Berpikir Kreatif E Motivasi Belajar Siswa. Pantera Publishing, 2019.

${ }^{6}$ Rizaldi, Dedi Riyan, Aris Doyan, Muh Makhrus, Ziadatul Fatimah, and Chester Ian Sotto Pineda. "The Relationship Between Learning Style and Critical Thinking Skills in Learning Kinetic Theory of Gases." Journal of Science and Science Education 2, no. 2 (2021): 72-76. 
This Training for Leaders and Herbalists (TRALIS) activity is an agenda that is held for the first time and is intended for Class XII. So that the object of research used is all students of class XII Department of Religion at Madrasah Aliyah Plus Nurul Islam Sekarbela with a total of 31 students. The choice of class XII as the object of research is because it is considered that students will soon face the final exam and as an initial provision to prepare for the next higher level. It is hoped that this activity can provide students with an understanding of the importance of motivation so that students are enthusiastic in learning or seeking knowledge.

\section{Findings and Disscusion \\ Learning Motivation}

Motivation comes from the Latin word, namely "movere" which means encouragement or driving force ${ }^{7}$. In a learning activity, motivation is needed to raise students' enthusiasm for learning so that learning activities can run well. This is because the overall driving force in students can encourage learning activities, ensure the continuity of learning activities, and provide direction for learning activities, so that the goals desired by the learning subjects can be achieved. Learning motivation is an internal and external encouragement for students who are learning to make changes in behavior ${ }^{8}$, generally with several indicators or supporting elements.

There are many kinds of motivation, because it can be seen from various points of view. There are several that are used in the learning process, namely motivation that comes from within a person's personality which is commonly called intrinsic motivation and motivation that comes from outside a person's personality which is commonly called extrinsic motivation ${ }^{9}$. The intrinsic motivation and extrinsic motivation ${ }^{10}$ are:

a. Intrinsic motivation, is the motivation that arises from the inside of a person. This motivation usually arises because of a person's hopes, goals,

${ }^{7}$ Widodo, Julistyono, Ayuwandira M. Morad, and Sri Hardina Syafruddin. "Analisis Prestasi Kerja Terhadap Motivasi Kerja Karyawan Pada PT. Pos Indonesia (Persero) Tolitoli." JAGOE: Journal Actual Organization Of Economic 2, no. 1 (2021): 105-110..

${ }^{8}$ Rizaldi, Dedi Riyan, A. Wahab Jufri, and Jamal Jamal. "PhET: Simulasi interaktif dalam proses pembelajaran fisika." Jurnal Ilmiah Profesi Pendidikan 5, no. 1 (2020): 10-14.

${ }^{9}$ Dewi, Vidiya Risna, Syamsuri Syamsuri, and Etika Khaerunnisa. "Karakteristik motivasi ekstrinsik dan intrinsik siswa SMP dalam belajar matematika." TIRTAMATH: Jurnal Penelitian dan Pengajaran Matematika 1, no. 2 (2019): 116-128.

${ }^{10}$ Septianti, Dian, and Melia Frastuti. "Pengaruh Penggunaan Media Berbasis Internet, Motivasi Intrinsik dan Motivasi Ekstrinsik Terhadap Minat Berwirausaha Online Mahasiswa Universitas Tridinanti Palembang." Jurnal Ilmiah Ekonomi Global Masa Kini 10, no. 2 (2019): 130-138. 
and desires for something so that he has the enthusiasm to achieve these conditions.

b. Extrinsic motivation, is something that is expected to be obtained from outside a person. This motivation is usually in the form of the value of a material, for example a reward in the form of money or other incentives obtained for an effort that has been made.

Learning motivation can arise due to several factors " ${ }^{\text {, }}$ namely:

a. Internal Factors

1. Physical factors, are factors that affect the body and individual appearance. Physical factors include nutrition (nutrition), health and physical functions, especially the five senses.

2. Psychological factors, are intrinsic factors related to aspects that encourage or hinder student learning activities. This factor concerns the spiritual condition of students.

b. External Factors

1. Social factors, are factors that come from humans around the student environment. Includes teachers, peers, parents, neighbors and so on,

2. Non-social factors are factors that come from the physical conditions around students. Includes air conditions (hot or cold weather), time (morning, afternoon or evening), place (quiet, noisy or the quality of the madrasa where students study), and learning facilities.

The elements that influence learning motivation are:

a. The ability of students, where the desire of a child needs to be balanced with the ability to achieve something. In summary, it can be said that the ability will strengthen children's motivation to carry out developmental tasks.

b. Student conditions, including physical and spiritual conditions affect learning motivation. A student who is sick, hungry or angry will interfere with learning attention. On the other hand, a healthy, full and happy student will focus on the explanation of the lesson. Thus, the physical and spiritual conditions of students affect the motivation to learn.

c. Students' environmental conditions, can be in the form of natural conditions, living environment, peer association, and social life.

\section{Training For Leaders and Herbalists (TRALIS) Activities}

The Training for Leaders and Herbalists (TRALIS) activity is an internship activity carried out by motivator students from the Radix Indonesia Emas Foundation for one month which is divided into eight meetings at Madrasah Aliyah Plus Nurul Islam Sekarbela. This activity is a form of

${ }^{11}$ Hariyadi, Ahmad, and Agus Darmuki. "Prestasi dan Motivasi Belajar dengan Konsep Diri." In Prosiding Seminar Nasional Penguatan Muatan Lokal Bahasa Daerah sebagai Pondasi Pendidikan Karakter Generasi Milenial, pp. 280-286. 2019. 
implementing the knowledge possessed by students to be applied to real problems, especially those related to the development of students in following the learning process.

The material presented in this activity is integrated with various knowledge sourced from the teachings of Islam (Al Qur'an) because the object of study in this activity is students who are in the environment of the Islamic boarding school foundation. In addition to focusing on materials in growing and increasing student motivation, this activity also provides various Islamic health methods that students can apply in their daily lives. The Training for Leaders and Herbalists (TRALIS) activities were carried out through eight meetings with the following material details:

1. Introduction to Motivation,

2. Increase Confidence,

3. Practice Discipline,

4. Explore Your Potential,

5. Forming Good Habits,

6. Achieving Goals with Full of Confidence,

7. Lifestyle and Thibbun Nabawi

8. Blood Cupping Practice

\section{Implementation of Training for Leaders and Herbalists (TRALIS)} Activities at Madrasah Aliyah Plus Nurul Islam Sekarbela

Training for Leaders and Herbalists (TRALIS) aims to revive students' learning motivation by training students' activeness in communicating, thereby changing students who were initially passive to become more active in the learning process ${ }^{12}$. In addition to this, students are also trained on discipline, and can help students find their potential ${ }^{13}$. This is in accordance with the function of motivation ${ }^{14}$, namely:

1. Determine the direction of action, namely towards the goal to be achieved. Thus, motivation can provide direction and activities that must be carried out in accordance with the formulation of goals.

2. Encouraging to act, so as a mover that releases energy. Motivation in this case is the driving force of every activity to be carried out.

\footnotetext{
${ }^{12}$ Pour, Agustina Novitasari, Lovy Herayanti, and Baiq Azmi Sukroyanti. "Pengaruh Model Pembelajaran Talking Stick terhadap Keaktifan Belajar Siswa." Jurnal Penelitian dan Pengkajian Ilmu Pendidikan: e-Saintika 2, no. 1 (2018): 3640

${ }^{13}$ Muzakki, Hawwin. "Teori Belajar Konstruktivisme Ki Hajar Dewantara serta Relevansinya dalam Kurikulum 2013." Southeast Asian Journal of Islamic Education Management 2, no. 2 (2021): 261-282.

${ }^{14}$ Tasrim, Tasrim, and Elihami Elihami. "Motivasi Kerja Pendidik dalam Meningkatkan Manajemen Lembaga Pendidikan Dasar." Mahaguru: Jurnal Pendidikan Guru Sekolah Dasar 1, no. 1 (2020): 48-53.
} 
3. Selecting actions, namely determining various actions that must be done in the hope of achieving the goal, by eliminating actions that are not useful for that purpose.

The Training for Leaders and Herbalists (TRALIS) will be held from 7 30 September 2021 and will take place twice face-to-face in one week, on Tuesdays and Thursdays. The activity was carried out at Madrasah Aliyah Plus Nurul Islam Sekarbela. The target in this activity is the Class XII students of the Department of Religion, totaling 31 people. The material given to students is not only in the form of theory, but is equipped with videos and Power Point $(\mathrm{PPT})^{15}$, where to maximize the material that can be well received by students, the activities are carried out in a face-to-face system.

The first to sixth meetings, the material is focused on motivational activities to re-enhance the spirit of learning and explore students' potential, as shown in the image below:
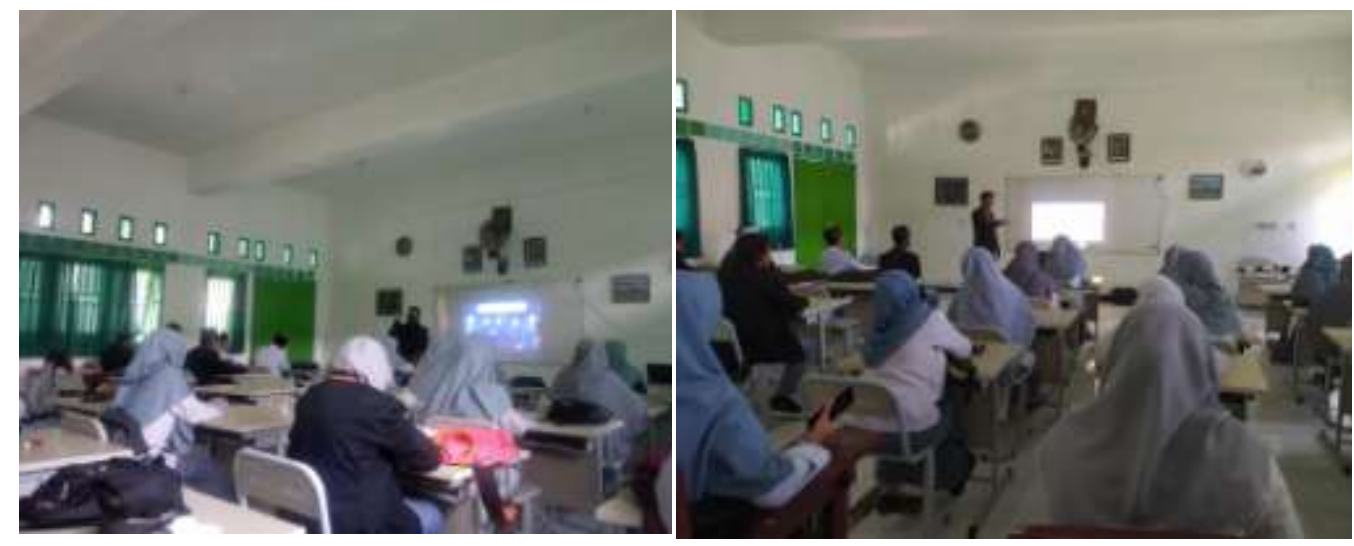

Figure 1. The Process of Submission of Materials to Increase Students' Learning Motivation

Motivation or enthusiasm for learning must be owned by students because it is a driving force or impetus that makes someone interested in returning to be able to learn continuously ${ }^{16}$. Low motivation can cause low success in learning so that it will reduce student achievement. This is in line

\footnotetext{
${ }^{15}$ Riyadi, Dias Syahrul, Nukhan Anwar, Risqina Putri Nurhidayati, Tanti Julianti, and Anaas Tri Ridlo Dina Yuliana. "Urgensi Pemanfaatan Media Pembelajaran PAI Berbasis Information And Comunication Technologies (ICT) Di Masa Pandemi Covid 19." EDUCANDUM 7, no. 1 (2021): 114-124.

${ }^{16}$ Roffina, Zamrat Desi. "MENINGKATKAN SEMANGAT BELAJAR SISWA DALAM PEMBELAJARAN RELASI DAN FUGSI MELALUI PENDEKATAN SCIENTIFIC." Jurnal Pendidikan Tambusai 4, no. 1 (2020): 810-820.
} 
with several previous studies by Palittin et al. $(2019)^{17}$ and Ricardo \& Meilani $(2017)^{18}$ which illustrate that good learning motivation will have a positive impact both simultaneously and partially on student learning outcomes. This is also emphasized in the research conducted by Fatimah et al. (2020) ${ }^{19}$; Simbolon (2014) ${ }^{20}$; Rizaldi, et al. (2020) $)^{21}$ that with good motivation in students it will cause the condition of the learning environment to bring pleasant nuances. This condition will certainly have a good impact on other children so that they can overall help the learning process ${ }^{22}$.

Activeness is needed in the learning process because it is a process of teaching and learning activities that require students to be actively involved in the learning process and make student behavior better. This is in accordance with the opinion of Nurhayati (2020)that students are active subjects in learning ${ }^{23}$. The success of students in a learning process is influenced by the quality of the student's activity.

\footnotetext{
${ }^{17}$ Palittin, Ivylentine Datu, Wilhelmus Wolo, and Ratna Purwanty. "Hubungan motivasi belajar dengan hasil belajar siswa." Magistra: Jurnal Keguruan dan Ilmu Pendidikan 6, no. 2 (2019): 101-109.

${ }^{18}$ Ricardo, R., and R. I. Meilani. "Impak Minat dan Motivasi Belajar terhadap Hasil Belajar Siswa (The impacts of students' learning interest and motivation on their learning outcomes)." Jurnal Pendidikan Manajemen Perkantoran 1, no. 1 (2017): 79-92.

${ }^{19}$ Fatimah, Ziadatul, Dedi Riyan Rizaldi, A. Wahab Jufri, and Jamaluddin Jamaluddin. "Model Inkuiri Terbimbing Berbantuan Laboratorium Virtual Untuk Meningkatkan Keterampilan Proses Sains." Jurnal Pendidikan, Sains, Geologi, dan Geofisika (GeoScienceEd Journal) 1, no. 2 (2020).

${ }^{20}$ Simbolon, Naeklan. "Faktor-faktor yang mempengaruhi minat belajar peserta didik." Elementary School Journal Pgsd Fip Unimed 1, no. 2 (2014).
}

${ }^{21}$ Rizaldi, Dedi Riyan, Ziadatul Fatimah, Miftahul Hasanah, Faisal Faisal, and Siti Handayani. "Pembelajaran Berbasis Berugak Pintar Untuk Meningkatkan Minat Belajar Anak di Desa Dasan Lekong." Jurnal Pengabdian Masyarakat Sains Indonesia 2, no. 2 (2020).

${ }^{22}$ Rizaldi, Dedi Riyan, Ziadatul Fatimah, Aris Doyan, And Muh Makhrus. "EFFORTS TO FAMILIARIZE LITERACY CULTURE IN STUDENTS: ORIENTATION IN THE MADRASAENVIRONMENT." International Journal of Social and Humanities Extension (IJSHE) (2021): 20-24.

${ }^{23}$ Nurhayati, Erlis. "Meningkatkan keaktifan siswa dalam pembelajaran daring melalui media game edukasi quiziz pada masa pencegahan penyebaran covid19." Jurnal Paedagogy 7, no. 3 (2020): 145-150. 


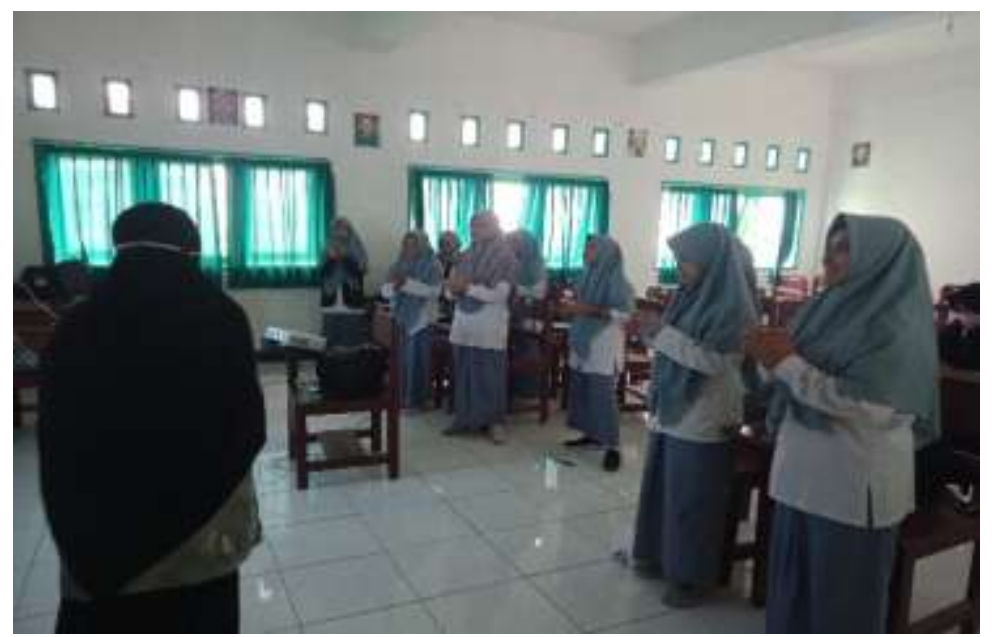

Figure 2. Forms of Student Participation in Training for Leaders and Herbalists (TRALIS) Activities

In the last two meetings, materials related to herbalism were given, namely the Lifestyle and Thibbun Nabawi and Cupping Practice. Herbalism is a form of treatment by utilizing various herbal medicines derived from plants, because they do not have side effects such as chemical drugs ${ }^{24}$. Herbal medicine generally uses ingredients or spices that are often encountered by students around their environment. Therefore, this knowledge can be used as a guide by students if one day they experience a problem in real life. This form of activity is one of the efforts to improve the soft skills of the students themselves. So it is hoped that after going through the process of this activity students not only have the ability to support during the learning process but also have skills that can be useful for themselves and society in the future ${ }^{25}$ (Nurhayati et al., 2020).

Based on the activities that have been carried out, there is a significant difference in student responses. At the initial meeting, students seemed to still tend to be lazy in receiving the material and look weak (less enthusiastic) in following the learning process. So that in the activity process, we try to increase student activity by providing various mini games and videos that attract students to ask questions, so that the ongoing activities become more active and in accordance with the objectives of the Training for Leaders and Herbalists (TRALIS) activities, namely increasing motivation. students in learning.

${ }^{24}$ al Cidadapi, Ibnu Eman. Ramuan Herbal ala Thibun Nabawi:" Mengupas pengobatan herbal di dalam Thibun Nabawi". Vol. 1. Putra Ayu, 2016.

${ }^{25}$ Nurhayati, Eris, Dedi Riyan Rizaldi, and Ziadatul Fatimah. "The Correlation of Digital Literation and STEM Integration to Improve Indonesian Students' Skills in 21st Century." Online Submission 1, no. 2 (2020): 73-80. 
The students themselves were very enthusiastic in participating in the Training for Leaders and Herbalists (TRALIS) activities. These activities are proven to bring change for students themselves. This makes students more enthusiastic in learning, and begins to set targets that will be taken when they have completed their education at the Madrasah Aliyah level in the future.

\section{Conclusion}

Based on the introduction, methods, results and discussion, it can be concluded that Training for Leaders and Herbalists (TRALIS) is an important positive activity given to students to raise the spirit of learning. This activity provides many new changes for students during the learning process, including students becoming more enthusiastic in learning and have started to dare to set targets in pursuing their goals.

\section{References}

al Cidadapi, Ibnu Eman. Ramuan Herbal ala Thibun Nabawi:" Mengupas pengobatan herbal di dalam Thibun Nabawi". Vol. 1. Putra Ayu, 2016.

Cahyani, Adhetya, Iin Diah Listiana, and Sari Puteri Deta Larasati. "Motivasi Belajar Siswa SMA pada Pembelajaran Daring di Masa Pandemi Covid19." IQ (Ilmu Al-qur'an): Jurnal Pendidikan Islam 3, no. o1 (2020): 123-140.

Cahyono, Hadi. "Faktor-Faktor Kesulitan Belajar Siswa Min Janti." JDPP Jurnal Dimensi Pendidikan dan Pembelajaran 7, no. 1 (2019): 1-4.

Dewi, Vidiya Risna, Syamsuri Syamsuri, and Etika Khaerunnisa. "Karakteristik motivasi ekstrinsik dan intrinsik siswa SMP dalam belajar matematika." TIRTAMATH: Jurnal Penelitian dan Pengajaran Matematika 1, no. 2 (2019): 116-128.

Fatimah, Ziadatul, Dedi Riyan Rizaldi, A. Wahab Jufri, and Jamaluddin Jamaluddin. "Model Inkuiri Terbimbing Berbantuan Laboratorium Virtual Untuk Meningkatkan Keterampilan Proses Sains." Jurnal Pendidikan, Sains, Geologi, dan Geofisika (GeoScienceEd Journal) 1, no. 2 (2020). 
Hariyadi, Ahmad, and Agus Darmuki. "Prestasi dan Motivasi Belajar dengan Konsep Diri." In Prosiding Seminar Nasional Penguatan Muatan Lokal Bahasa Daerah sebagai Pondasi Pendidikan Karakter Generasi Milenial, pp. 280-286. 2019.

Harisuddin, Muhammad Iqbal. Secuil Esensi Berpikir Kreatif E Motivasi Belajar Siswa. Pantera Publishing, 2019.

Muzakki, Hawwin. "Teori Belajar Konstruktivisme Ki Hajar Dewantara serta Relevansinya dalam Kurikulum 2013." Southeast Asian Journal of Islamic Education Management 2, no. 2 (2021): 261-282.

Nurhayati, Erlis. "Meningkatkan keaktifan siswa dalam pembelajaran daring melalui media game edukasi quiziz pada masa pencegahan penyebaran covid-19." Jurnal Paedagogy 7, no. 3 (2020): 145-150.

Nurhayati, Eris, Dedi Riyan Rizaldi, and Ziadatul Fatimah. "The Correlation of Digital Literation and STEM Integration to Improve Indonesian Students' Skills in 21st Century." Online Submission 1, no. 2 (2020): 7380.

Palittin, Ivylentine Datu, Wilhelmus Wolo, and Ratna Purwanty. "Hubungan motivasi belajar dengan hasil belajar siswa." Magistra: Jurnal Keguruan dan Ilmu Pendidikan 6, no. 2 (2019): 101-109.

Pour, Agustina Novitasari, Lovy Herayanti, and Baiq Azmi Sukroyanti. "Pengaruh Model Pembelajaran Talking Stick terhadap Keaktifan Belajar Siswa." Jurnal Penelitian dan Pengkajian Ilmu Pendidikan: e-Saintika 2, no. 1 (2018): 36-40.

Ricardo, R., and R. I. Meilani. "Impak Minat dan Motivasi Belajar terhadap Hasil Belajar Siswa (The impacts of students' learning interest and motivation on their learning outcomes)." Jurnal Pendidikan Manajemen Perkantoran 1, no. 1 (2017): 79-92.

Riyadi, Dias Syahrul, Nukhan Anwar, Risqina Putri Nurhidayati, Tanti Julianti, and Anaas Tri Ridlo Dina Yuliana. "Urgensi Pemanfaatan Media Pembelajaran PAI Berbasis Information And Comunication Technologies (ICT) Di Masa Pandemi Covid 19." EDUCANDUM 7, no. 1 (2021): 114-124. 
Rizaldi, Dedi Riyan, A. Wahab Jufri, and Jamal Jamal. "PhET: Simulasi interaktif dalam proses pembelajaran fisika." Jurnal Ilmiah Profesi Pendidikan 5, no. 1 (2020): 10-14.

Rizaldi, Dedi Riyan, Ziadatul Fatimah, Miftahul Hasanah, Faisal Faisal, and Siti Handayani. "Pembelajaran Berbasis Berugak Pintar Untuk Meningkatkan Minat Belajar Anak di Desa Dasan Lekong." Jurnal Pengabdian Masyarakat Sains Indonesia 2, no. 2 (2020).

Rizaldi, Dedi Riyan, Aris Doyan, Muh Makhrus, Ziadatul Fatimah, and Eris Nurhayati. "Adaptation to new normal conditions: Students physics learning outcomes using the blended learning model." International Journal of Asian Education 2, no. 3 (2021): 369-376.

Rizaldi, Dedi Riyan, Aris Doyan, Muh Makhrus, Ziadatul Fatimah, and Chester Ian Sotto Pineda. "The Relationship Between Learning Style and Critical Thinking Skills in Learning Kinetic Theory of Gases." Journal of Science and Science Education 2, no. 2 (2021): 72-76.

Rizaldi, Dedi Riyan, Ziadatul Fatimah, Aris Doyan, And Muh Makhrus. "EFFORTS TO FAMILIARIZE LITERACY CULTURE IN STUDENTS: ORIENTATION IN THE MADRASA ENVIRONMENT." International Journal of Social and Humanities Extension (IJSHE) (2021): 20-24.

Roffina, Zamrat Desi. "MENINGKATKAN SEMANGAT BELAJAR SISWA DALAM PEMBELAJARAN RELASI DAN FUGSI MELALUI PENDEKATAN SCIENTIFIC." Jurnal Pendidikan Tambusai 4, no. 1 (2020): 810-820.

Septianti, Dian, and Melia Frastuti. "Pengaruh Penggunaan Media Berbasis Internet, Motivasi Intrinsik dan Motivasi Ekstrinsik Terhadap Minat Berwirausaha Online Mahasiswa Universitas Tridinanti Palembang." Jurnal Ilmiah Ekonomi Global Masa Kini 10, no. 2 (2019): 130-138.

Setiawan, Farid, Dias Syahrul Riyadi, Shinta Ledia, and Yayan Bagus Duandanto. "Peran Pendidik dalam Meningkatkan Manajemen Sekolah pada Masa Pandemi." MASALIQ 1, no. 3 (2021): 33-49.

Simbolon, Naeklan. "Faktor-faktor yang mempengaruhi minat belajar peserta didik." Elementary School Journal Pgsd Fip Unimed 1, no. 2 (2014). 
Tasrim, Tasrim, and Elihami Elihami. "Motivasi Kerja Pendidik dalam Meningkatkan Manajemen Lembaga Pendidikan Dasar." Mahaguru: Jurnal Pendidikan Guru Sekolah Dasar 1, no. 1 (2020): 48-53.

Widodo, Julistyono, Ayuwandira M. Morad, and Sri Hardina Syafruddin. "Analisis Prestasi Kerja Terhadap Motivasi Kerja Karyawan Pada PT. Pos Indonesia (Persero) Tolitoli." JAGOE: Journal Actual Organization Of Economic 2, no. 1 (2021): 105-110. 
SOUTHEAST ASIAN JOURNAL OF ISLAMIC EDUCATION MANAGEMENT 3 (1) 2022 